\title{
Beta Carotene Intake and Oral Cancer Risk
}

\author{
Helen-Ng LC ${ }^{1 *}$, Razak IA ${ }^{1,2}$, Ghani WMN¹, Marhazlinda J³, Rahman ZAA ${ }^{5}$, Norlida A ${ }^{4}$, Zain RB ${ }^{1,5}$ \\ ${ }^{1}$ Oral Cancer Research \& Coordinating Centre, Faculty of Dentistry, University Malaya, Kuala Lumpur, Malaysia \\ ${ }^{2}$ Department of Community Oral Health and Clinical Prevention, Faculty of Dentistry, University Malaya, Kuala \\ Lumpur, Malaysia \\ ${ }^{3}$ Dental Research \& Training Unit, Faculty of Dentistry, University Malaya, Kuala Lumpur, Malaysia \\ ${ }^{4}$ Oral Health Division, Ministry of Health, Putrajaya, Malaysia \\ ${ }^{5}$ Department of Oro \& Maxillofacial Surgical and Medical Sciences, Faculty of Dentistry, University Malaya, Kuala \\ Lumpur, Malaysia
}

\begin{abstract}
Objectives: This study aims to identify the relationship between dietary intakes of $\beta$-carotene with risk of oral cancer. Methods: A hospital-based, case-control study was conducted on 306 Malaysians who seek treatment at participating centres/hospitals. Subjects selected from the Malaysian Oral Cancer Data and Tissue Banking System (MOCDTBS) consisted of 153 cases and 153 controls that were matched for gender, age ( \pm 5 years) and ethnicity. Food consumption was measured using Food Frequency Questionnaire (FFQ). NutrieMart Version 2.0.0 software was used to estimate daily nutrient of each subject from the FFQ. Logistic Regression analysis was conducted to compute the odds ratio (OR) for intakes of $\beta$-carotene and oral cancer risk. Results: Intake of $\beta$-carotene was found to be not associated with risk of oral cancer (OR $0.83,95 \% \mathrm{Cl}: 0.42-1.66, p>0.05)$. Conclusion: No significant association was found between dietary intakes of $\beta$-carotene with oral cancer risk in this study population.
\end{abstract}

Keywords: $\beta$-carotene, Dietary Intake, Oral Cancer.

\section{INTRODUCTION}

Carotenoids are known to provide antioxidant properties and have mostly been associated with a reduced risk for cardiovascular diseases, macular degeneration and ageing. Studies have also shown that carotenoids play an important role in protection against cancer due to their strong antioxidant capacity in neutralizing free radicals in the body. Moreover, the chain structure of $\beta$-carotene enables the promotion of normal cell differentiation and inhibition of cancerous aberrant cell growth and cell proliferation (1). The most common form of carotenoids which is also the precursor of Vitamin A is known as $\beta$-carotene, a fat soluble vitamin.
Most research studies on phytochemicals or vitamins and their associations with cancer or cancer prevention focussed on $\beta$-carotene. Strong associations between $\beta$-carotene and lowered risk of lung cancer have been reported (2). Recent studies also suggested a protective effect of carotenoids against other cancer sites such as oesophagus, stomach colon, rectum, breast and cervix (1). Additionally, $\beta$-carotene has been found to exhibit beneficial effects in terms of human immune function and enhancement of cell to cell communication (3). Moreover, $\beta$-carotene was found to boost proliferation of $T$ and $B$ lymphocytes which act as natural killer cells while helping to decrease chromosomal abnormalities (4). 
Clinical interventions trials involving human studies have reported the response rate of oral leukoplakia to $\beta$-carotene to be as high as $44-71 \%$ without significant toxicity (5). Similarly, a combination of $30 \mathrm{mg}$ of $\beta$-carotene, $1000 \mathrm{mg}$ ascorbic acid and $8001 \mathrm{U}$ of $\alpha$-tocopherol per day for 9 months have also shown marked clinical improvement in $56 \%$ of patients (5). Consistently, supplementation with 30$60 \mathrm{mg}$ of $\beta$-carotene for approximately 6 months has also been proven to be effective in suppressing oral leukoplakia of up to $50-60 \%$ during the early phases of the disease (6). Reviews of one epidemiological studies indicated that high intakes of $\beta$-carotene-rich vegetables and fruits or high blood concentrations of $\beta$-carotene confer to significant inverse association with the risk of lung cancer (3).

To date, published data on the relationship between food intake and oral cancer in a Malaysian population remain scant. A preliminary study by Zain et.al., (7) which investigates the relationship of serum micronutrients level with oral cancer and pre cancer prevalence among selected ethnic groups (Indian and Malays) noted that serum level of alphatocopherol, zeaxanthin/lutein and $\beta$-carotene were found to be significantly lower in patients with oral cancer and pre cancer as compared to those without lesions $(7,8)$. Recent study has noted that high serum levels of retinol $(\mathrm{OR}=0.501)$ and $\alpha$-tocopherol $(0.184)$ confer protection but no relationship was observed between $\beta$-carotene with oral cancer risk (9). So the aim of this study is to determine the association between Recommended Nutrient Intake $(\mathrm{RNI})$ of $\beta$-carotene with oral cancer risk.

\section{METHODOLOGY}

\section{Study Design and Subjects Selection}

This is a case-control hospital-based study. A total of 153 cases and 153 control patients were recruited in this research study. The sample size is based on past studies to estimate the prevalence of oral cancer risk (10). The case and control patients were matched for age ( \pm 5 years), gender and ethnicity. Only Malaysian citizens were considered for this present study. Cases were patients with histologically diagnosed oral squamous cell carcinoma (OSCC). Control patients were taken from a pool of healthy individuals without the disease of interest. In this study, for both the cases and controls, only respondents with a complete dietary data set and information were included. A signed informed and written consent was obtained from all the respondents. The research protocol for this study was approved by Ethics Committee [DFOP 0306/0018/(L)].

\section{Data Collection for Dietary Assessment}

Data were extracted from the Malaysian Oral Cancer Database and Tissue Bank System (MOCDTBS). Relevant data such as information on sociodemographic background and risk habits which includes tobacco smoking, alcohol drinking and betel quid chewing were obtained for each subject.

A structured semi quantitative food frequency questionnaire (FFQ) was developed and validated for the Malaysian population to collect information on the respondent's dietary intake. The FFQ consists of 99 food items and beverages, which were grouped into 9 different categories based on similarities in nutrient profile. Quantification of food intake was measured using commonly used unit or serving sizes as per the guidelines from the Nutrient Composition of Malaysian Foods (11). The respondents were asked to indicate the average weekly frequency of consumption over the past years for each of the dietary item.

\section{Statistical Analysis}

Dietary data obtained from FFQ were transformed numerically based on the mean daily equivalent and were computed for quantitative meaningful data (12). These quantitative data were then keyed into the NutrieMart Version 2.0.0 software to compute the daily nutrient intake for each of the food items. In this study, the dietary value of $\beta$-carotene intake as derived from NutrieMart software is divided into two different categories namely high intake of $\beta$-carotene or low intake of $\beta$-carotene which was based on the Recommended Nutrient Intakes (RNI), 2005 for Malaysia. The RNI (11) for men and women aged 16 to 65 years are recommended to consume $500 \mathrm{ug}$ Vitamin A in their daily diet.

Conditional logistic regression analysis from SPSS (Social Package and Statistical Software) was used to identify association between intake of $\beta$-carotene and oral cancer risk whereby $95 \% \mathrm{Cl}$ of the Odd Ratio $(\mathrm{OR})$, were used to estimate precision of the coefficient to its standard error in order to make inferences to the study population (13).

\section{RESULTS}

The socio-demographic characteristics and the practice of risk habits of the study sample are shown in Table 1.

The age range for oral cancer patients in this study was $18-82$ years (mean age of $52.4 \pm 12.8$ ) 
while that of the control patients was 17-81 years (mean age of $52.4 \pm 12.6$ ). The prevalence of oral cancer in the sample increases with increasing age group. More than $60 \%$ of the cancer cases were seen in $\geq 50$ years age group and males accounted for slightly more than half of the study sample.

Table 1: Socio-demographic characteristics and risk habits of subjects

\begin{tabular}{|c|c|c|c|c|}
\hline $\begin{array}{l}\text { Socio- } \\
\text { demographic } \\
\text { parameter }\end{array}$ & $\begin{array}{l}\text { Control } \\
\mathrm{N}=153 \\
(\%)\end{array}$ & $\begin{array}{l}\text { Cases } \\
\mathrm{N}=153 \\
(\%)\end{array}$ & $\begin{array}{l}X^{2} \\
\text { statistics } \\
\text { (df) }\end{array}$ & p-value \\
\hline $\begin{array}{l}\text { Age (years) } \\
<35 \text { years old } \\
35-49 \text { years } \\
\text { old } \\
\geq 50 \text { years old }\end{array}$ & $\begin{array}{l}14(9.2) \\
42(27.5) \\
97(63.4)\end{array}$ & $\begin{array}{l}16(10.5) \\
41(26.8) \\
96(62.7)\end{array}$ & 0.151 & 0.927 \\
\hline $\begin{array}{l}\text { Gender } \\
\text { Male } \\
\text { Female }\end{array}$ & $\begin{array}{l}81(52.9) \\
72(47.1)\end{array}$ & $\begin{array}{l}81(52.9) \\
72(47.1)\end{array}$ & 0.000 & 1.000 \\
\hline $\begin{array}{l}\text { Ethnicity } \\
\text { Malay } \\
\text { Chinese } \\
\text { Indian }\end{array}$ & $\begin{array}{l}51(33.3) \\
51(33.3) \\
51(33.3)\end{array}$ & $\begin{array}{l}51(33.3) \\
51(33.3) \\
51(33.3)\end{array}$ & 0.000 & 1.000 \\
\hline $\begin{array}{l}\text { Risk Habits } \\
\text { a) Smoking } \\
\text { status } \\
\text { No } \\
\text { Yes }\end{array}$ & $\begin{array}{l}126(82.4) \\
27(17.6)\end{array}$ & $\begin{array}{l}87(56.9) \\
66(43.1)\end{array}$ & 23.496 & 0.000 \\
\hline $\begin{array}{l}\text { b) Alcohol } \\
\text { drinking } \\
\text { status } \\
\text { No } \\
\text { Yes }\end{array}$ & $\begin{array}{l}132(86.3) \\
21(13.7)\end{array}$ & $\begin{array}{l}105(68.6) \\
48(31.4)\end{array}$ & 13.641 & 0.000 \\
\hline $\begin{array}{l}\text { c) Betel-quid } \\
\text { chewing } \\
\text { status } \\
\text { No } \\
\text { Yes }\end{array}$ & $\begin{array}{l}126(82.4) \\
27(17.6)\end{array}$ & $\begin{array}{l}104(68.0) \\
49(32.0)\end{array}$ & 8.473 & 0.004 \\
\hline $\begin{array}{l}\text { Family } \\
\text { History of } \\
\text { Cancer } \\
\text { No } \\
\text { Yes }\end{array}$ & $\begin{array}{l}129(84.3) \\
24(15.7)\end{array}$ & $\begin{array}{l}118(77.1) \\
35(22.9)\end{array}$ & 2.541 & 0.111 \\
\hline
\end{tabular}

Significance differences were detected in the practice of all three risk habits. The proportion of smokers $(43.1 \%)$, drinkers $(31.4 \%)$ and chewers $(32.0 \%)$ were significantly higher among the cases as compared to the controls of $17.6 \%, 13.7 \%$ and $17.6 \%$ respectively.
Although the prevalence of oral cancer was higher in those who had a past family history of cancer as compared to those who do not with a ratio of $6: 4$, the difference was not statistically significant.

Table 2 summarizes the effect of dietary $\beta$-carotene intakes and oral cancer risk at univariate level. The mean dietary intakes of $\beta$-carotene for cases and control were $253.8 \pm 234.8$ and $290.1 \pm 243.4$ respectively. According to Recommended Nutrient Intakes (RNI), 2005 the intake of $\beta$-carotene was low for $86.9 \%$ of cases and $88.9 \%$ controls. A higher percentage of control subjects, $13.1 \%$ were observed to have consumed high $\beta$-carotene daily as compared to cases $11.1 \%$. It was observed that although there is a trend of lower risk of oral cancer with high $\beta$-carotene intake, this association was not found to be statistically significant $(O R=0.83,95 \%$ $\mathrm{Cl}=0.417-1.656, \mathrm{p}>0.05)$.

Table 2: Association between dietary $\beta$-carotene intake and oral cancer risk

\begin{tabular}{lccccc}
\hline $\begin{array}{l}\text { Dietary } \\
\beta-\end{array}$ & $\begin{array}{c}\text { Case } \\
(\%) \\
\text { Carotene } \\
\text { Intake }\end{array}$ & $\begin{array}{c}\text { Control } \\
(\mathbf{N}=153)\end{array}$ & $\begin{array}{c}\mathbf{X}^{2} \\
(\mathbf{N}=153)\end{array}$ & $\begin{array}{c}\text { p-value } \\
\text { stistics } \\
(\mathbf{d f})\end{array}$ & $\begin{array}{c}\text { Crude OR } \\
(95 \% \mathrm{Cl})\end{array}$ \\
$\begin{array}{l}\text { Low } \\
\text { (below }\end{array}$ & 136 & 133 & 0.277 & 0.599 & 1.000 \\
RNI) & $(88.9)$ & $(86.9)$ & & & \\
High & 17 & 20 & & & 0.831 \\
(above & $(11.1)$ & $(13.1)$ & & & $(0.417-$ \\
RNI) & & & & & $1.656)$ \\
\hline
\end{tabular}

\section{DISCUSSION}

Vegetables and fruits have rich resource of nutrients with validated anti-oxidant properties such as $\beta$-carotene, Vitamin $C$ and $\alpha$-tocopherol. These nutrients occur naturally and are potent regulators of cellular activities and have significant impact on oral carcinogenesis (14). $\beta$-carotene may help in preventing tissue damage by trapping organic free radicals and/or deactivating excited oxygen molecules. In this study, no statistically significant association was found between high intake of carotene and risk of oral cancer. In contrast, many epidemiological studies suggest that low dietary intake and low plasma concentration of antioxidant vitamin such as $\beta$-carotene are associated with increased risk of several types of cancer $(5,15-16)$. 
The contrasting finding in this present study could be due to the highly skewed distribution of $\beta$-carotene consumption of respondents towards low intake in their daily diet. This findings is also consistent with the results obtained where serum level of $\beta$-carotene among cases $(0.106 \pm 0.159 \mu \mathrm{g} / \mathrm{ml})$ were lower as compared to controls $(0.134 \pm 0.131 \mu \mathrm{g} /$ $\mathrm{ml}$ ) in which statistical significance was not observed as well (9). More than $85 \%$ of all the case and control subjects do not meet the daily Recommended Nutrient Intake (RNI) as provided by the national guideline (11). This shows that the Malaysian population does not consume enough vitamins from dietary sources to significantly produce acceptable results. It is also interesting to note that in an earlier study on dietary pattern, the 'prudent' diet, which comprises of fruits and vegetables (rich sources of $\beta$-carotene), also showed no significant association with oral cancer risk (17). Petridou et. al., (18) and Maserejian et. al., (19) also reported no significant association between intake of carotene; $\beta$-carotene-rich fruits and vegetables with oral cancer risk (18-19).

The role of $\beta$-carotene in oral cancer development is conflicting where no clear evidence is found as reported in a review study by Chainani$\mathrm{Wu}$ (20). Studies from a single vitamin (nutrient) did not found any protective effect on oral cancer risk. However, when multiple vitamins such as $\beta$-carotene, vitamin $C$ and selected flavonoids were studied synergistically, it has been found to provide reduced risk of oral cancer (20). Furthermore, previous studies were conducted in different populations worldwide whereby the average intake of $\beta$-carotene in these population may differ quite substantially thus resulting in contradicting results obtained (21-22).

An important aspect that needs consideration in terms of $\beta$-carotene intake is the method of food preparation. Association between $\beta$-carotene with oral cancer risk is not attributed only by the nutrient from the food itself, but is also influenced by the method of preparation of foods. Fruits and vegetables are easily oxidized when it is exposed in the air or cooked under heat for a long period of time resulting in depletion of all vitamins and minerals. Foods that are eaten raw are believed to have higher level of antioxidants properties as the constituent of chemical component still remains intact in the plant itself as compared to the foods that have already been cooked as these vitamins may have been destroyed during the process of cooking $(9,16)$. Currently, the mechanism in which $\beta$-carotene inhibits or reduces oral cancer risk and progression is still unclear.
In this study population, the failure to demonstrate any association between intake of $\beta$-carotene and oral cancer risk could be partly due to a lack of statistical power. Thus, a larger sample size is required for future case control studies of this nature, using population based controls which would give a much better spread of $\beta$-carotene consumption. Besides that, retrospective data collection using FFQ measurement tends to be plagued by recall bias which would ultimately affects the reporting of the dietary intake. Therefore, future research on human intervention trial and measurement of nutrient level via biochemical assessment is very much needed to establish a proper link between micronutrient intakes and oral cancer risk.

\section{CONCLUSION}

No significant association was observed between intake of $\beta$-carotene with the risk of oral cancer (OR $0.83,95 \% \mathrm{Cl}: 0.42-1.66, p>0.05$ ).

\section{ACKNOWLEDGEMENT}

This study was supported by the research grants from Ministry Of Science and Technology and Innovation (MOSTI), Malaysia (No: 06-02-03-0174 PR 0054/05-05) and Post Graduate Research Fund (PPP), University of Malaya (No: PS171/2010B). We would like to thank all surgeons and research clerks from Dental Faculty, Universiti Malaya (UM), Universiti Sains Malaysia (USM) and the Ministry of Health, Malaysia Dental Specialist Clinic at General Hospital of Kuala Lumpur, Klang (Selangor), Ipoh (Perak), Kota Bahru (Kelantan), Kuching (Sarawak) and Kota Kinabalu (Sabah) for their involvement in data collection.

\section{REFERENCES}

1. Simon JJ. Phytochemicals \& Cancer. J Chiropr Med. 2008; 3(1):91-96.

2. Donaldson MS. Nutrition and Cancer: A review of the evidence for anti-cancer diet. Nutr j 2004; 3(1):19.

3. Greenwald P, Clifford CK and Milner JA. Diet and cancer prevention. Eur. J. Cancer. 2001; 37(8):948-965.

4. Burri BJ. Beta-Carotene and Human Health: A Review of Current Research. Nutr Res. 1997; 17(3):547-580. 
5. Khaodhiar L. and Blackburn GL. Nutritional Oncology 2nd Edition. In Heber D, Blackburn GL, Go VLW and Milner J. (ed), Dietary Interventions. USA: Elsevier Inc. 2006: pp 779805.

6. Naves MMV and Moren FS. $\beta$-carotene and Cancer Chemoprevention: From Epidemiological Associations to Cellular Mechanisms of Action. Nutr Res. 1998; 18(10):1807-1824.

7. Zain RB, Ikeda N, Razak IA, Axell T, Majid ZA, Gupta PC and Yaacob M. A national epidemiological survey of oral mucosal lesions in Malaysia. Community Dent Oral Epidemiol. 1997; 25(5):377-383.

8. Zain RB. Cultural and dietary risk factors of oral cancer and precancer - a brief overview. Oral Oncol. 2001; 37:205-210.

9. Athirajan V, Razak IA, Thurairajah N, Ghani WMN, Helen-Ng LC, Yi-Hsin Y, Karen-Ng LP, Zainal Ariff AR, Wan Mustafa WM, Abrahan MT, Tay KK, Yuen KM, Jalil N, Zain RB. High Serum Level of Retinol and $\alpha$-Tocopherol Affords Protection Against Oral Cancer in a Multiethnic Population. Asian Pac J Cancer Prev. 2014; 15(19):8183-8189.

10. Amtha R, Zain R, Razak IA, Basuki B, Roeslan BO, Gautama W and Purwanto DJ. Dietary patterns and risk of oral cancer: A factor analysis study in Jakarta population Indonesia. Oral Oncol. 2009; 45(8):49e-53e.

11. Tee ES, Ismail MN, Nasir MA and Idris K. $4^{\text {th }}$ Edition ( $3^{\text {rd }}$ Printing) Nutrient Composition of Malaysian Foods for Malaysian Food Composition Database Programme, Institute Medical Research (IMR), Kuala Lumpur 1997.

12. Moynihan P, Thomason M, Walls A, GrayDonald K, Morais JA, Ghanem H, Wollin S, Ellis $\mathrm{J}$, Steele J, Lund $\mathrm{J}$ and Feine J. Researching the impact of oral health status on diet and nutritional status: Methodological issues. J Dent. 2009; 37(4):237-249.

13. Zheng T, Boyle P, Willett WC, Hu H, Dan J, Evstifeeva TV, Niu S and MacMohan B. A casecontrol study of oral cancer in Beijing, People's Republic of China. Association with nutrient intakes, food and food groups. Oral Oncol. 1993; 29(1):45-55.

14. Steinmetz KA and Potter JD. Vegetables, Fruit and Cancer Prevention: A review. J. Acad. Nutr. Diet. 1996; 96(10):1027-1039.
15. Vecchia CL, Altieri A and Tavani A. Vegetables, fruit, antioxidants and cancer: A review of Italian studies. Eur J Nutr. 2001; 40:261-267.

16. Enwonwu $\mathrm{CO}$ and Meeks VI. Bionutrition and Oral Cancer in Humans. Crit Rev Oral Biol M. 1995; 6(1):5-17.

17. Helen-Ng LC, Razak IA, Ghani WMN, Marhazlinda J, Norain AT, Raja Latifah RJ, Zainal Ariff AR, Norlida A, Zain RB. Dietary Pattern and Oral Cancer Risk: A Factor Analysis Study. Community Dent Oral Epidemiol. 2012; 40:560-566.

18. Petridou E, Zavras Al, Lefatzis D, Dessypris N, Laskaris G, Dokianakis G, Segas J, Douglas CW. DiehI SR and Trichopoulos D. The Role of Diet and Specific Micronutrients in the Etiology of Oral Carcinoma. American Cancer Society. 2002; 94:2981-2988.

19. Maserejian NM, Giovannucci E, Rosner B, Zavras A and Joshipura K. Prospective Study of Fruits and Vegetables and Risk of Oral Premaglinant Lesions in Men. Am J Epidemiol. 2006; 164:556-566.

20. Chainani-Wu, N. Diet and Oral, Pharyngeal and Esophageal Cancer. Nutr. Cancer. 2002; 44(2):104-126.

21. Lucenteforte E, Garavello W, Bosetti C and Vecchia CL. Dietary factors and oral pharyngeal cancer risk. Oral Oncol. 2009; 45(6):461-467.

22. Mayne ST. Beta-carotene, carotenoids and disease prevention in humans. FASEB (Fed Am Soc Exp Biol) J. 1996; 10:690-701.

\section{Corresponding author:}

\section{Helen Ng Lee Ching}

Oral Cancer Research \& Coordinating Centre, Faculty of Dentistry, University Malaya, 50603, Lembah Pantai, Kuala Lumpur, Malaysia

Tel: +603-79676460; Fax: +603-79547301

E-mail Address: leeching_helen@um.edu.my 